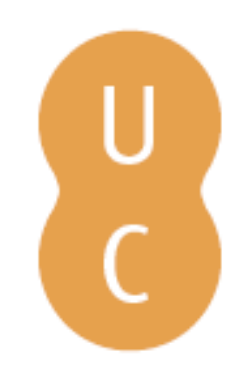

\title{
pompalina
}

\section{Teaching information literacy: a (new) core task for the university libraries in Germany}

\author{
Autor(es): $\quad$ Franke, Fabian \\ Publicado por: Imprensa da Universidade de Coimbra \\ URL \\ persistente: URI:http://hdl.handle.net/10316.2/36989 \\ DOI: $\quad$ DOI:http://dx.doi.org/10.14195/978-989-26-1045-0_18 \\ Accessed : $\quad$ 26-Apr-2023 09:24:42
}

A navegação consulta e descarregamento dos títulos inseridos nas Bibliotecas Digitais UC Digitalis, UC Pombalina e UC Impactum, pressupõem a aceitação plena e sem reservas dos Termos e Condições de Uso destas Bibliotecas Digitais, disponíveis em https://digitalis.uc.pt/pt-pt/termos.

Conforme exposto nos referidos Termos e Condições de Uso, o descarregamento de títulos de acesso restrito requer uma licença válida de autorização devendo o utilizador aceder ao(s) documento(s) a partir de um endereço de IP da instituição detentora da supramencionada licença.

Ao utilizador é apenas permitido o descarregamento para uso pessoal, pelo que o emprego do(s) título(s) descarregado(s) para outro fim, designadamente comercial, carece de autorização do respetivo autor ou editor da obra.

Na medida em que todas as obras da UC Digitalis se encontram protegidas pelo Código do Direito de Autor e Direitos Conexos e demais legislação aplicável, toda a cópia, parcial ou total, deste documento, nos casos em que é legalmente admitida, deverá conter ou fazer-se acompanhar por este aviso.

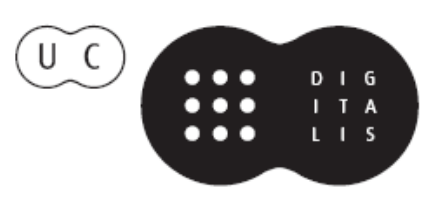



Tendo como pano de fundo as Comemorações dos seus 500 anos, a Biblioteca Geral da Universidade de Coimbra organizou um Congresso Internacional subordinado ao tema "A Biblioteca da Universidade: permanência e metamorfoses", que teve lugar nos dias 16, 17 e 18 de janeiro de 2014, no auditório da Reitoria da Universidade de Coimbra.

O objetivo maior desta reunião científica foi o de refletir sobre o presente e o futuro das bibliotecas que servem públicos universitários. Numa outra vertente, procurou chamar-se a atenção para a importância de que a Biblioteca se reveste, tendo em vista o progresso do conhecimento técnico e científico. Por último, o Congresso pretendeu instituir-se como oportunidade de reflexão prospetiva e como lugar de encontro entre as sensibilidades de todos os que trabalham profissionalmente com livros e com outros suportes de natureza bibliográfica.

Nesse sentido, foram apresentadas Conferências, Mesas Redondas e sessões de Testemunhos em torno de temas como o valor das bibliotecas universitárias, a biblioteca universitária em contexto; as mudanças e os desafios; a biblioteca universitária e a sociedade da informação e conhecimento; o impacto do acesso aberto na comunidade científica, e as bibliotecas digitais. 
FABIAN FRANKE

Universitätsbibliothek Bamberg

Universidade de Bamberg

TEACHING IN F ORMATION LITERACY:

A (NEW) CORE TASK FOR THE UNIVERSITY

LI B RARIES IN G ERMANY

ENSINO DA LITERACIA DA INFORMAÇÃO:

UMA (NOVA) TAREFA CENTRAL PARA BIBLIOTECAS

UNIVERSITÁrias NA ALEMANHA

RESUMO: O ensino da literacia da informação tornou-se uma questão central nas bibliotecas universitárias da Alemanha. A Conferência de Reitores Alemã recomendou integrar cursos de literacia de informação nos planos curriculares e reforçar o papel das bibliotecas, com o fim de criar novas estruturas de informação. Esta contribuição fornece uma visão geral das atividades de literacia da informação nas bibliotecas universitárias alemãs, analisando estatísticas nacionais de alfabetização de informação, discutindo os seus padrões e apresentando as melhores práticas em bibliotecas universitárias na Alemanha. Centra-se, em particular, nas iniciativas de cooperação com base em grupos de trabalho regionais de alfabetização de informação e da Comissão Nacional da Associação Alemã de Bibliotecas para a literacia da informação.

ABSTRACT: Teaching information literacy has become a core issue of German university libraries. The German rector's conference has recommended integrating information literacy courses into the curricula and enhancing the role of the libraries in order to create new information structures. This contribution gives an overview over the information literacy activities of the German university libraries. It analyzes the results of the national information literacy statistics, discusses the standards of information literacy in Germany and presents best practice at university libraries in Germany. A special focus lies on the cooperative initiatives based on the regional information literacy working groups and the national Commission for information literacy of the German library association. 


\section{Introduction}

The Association of College and Research Libraries defines information literacy as a "set of abilities requiring individuals to recognize when information is needed and have the ability to locate, evaluate, and use effectively the needed information"1. Our statement is: Teaching information literacy has become a core task for the university libraries in Germany. We speak of a library core task, if it is widely accepted by science and politics, if it is reflected in large statistical data and if libraries collaborate and cooperate in networks and establish standards in order to fulfill the task. This contribution gives an overview over the information literacy activities of the German university libraries. It analyzes the results of the national information literacy statistics, discusses the standards of information literacy in Germany and proves the initial statement.

\section{Information Literacy in Science and Politics}

Information literacy has become a major issue in many prominent papers, resolutions and recommendations of political and scientific panels in Germany. Three examples show the increased relevance of information literacy in the context of lifelong learning:

The German Rectors' Conference points out an extended understanding of information literacy which includes also data management and organizational processes ${ }^{2}$. The German Rectors' Conference requires that

- "Courses on teaching information competency should be anchored more firmly in curricula than has been the case until now and should be offered as widely as possible."

1 ASSOCIATION OF COLLEGE \& RESEARCH LIBRARIES - Information literacy competency standards for higher education. [Em linha]. Chicago: ACRL, 2000. [Consult 15 jan. 2014]. Disponível na WWW em: <URL:http://www.ala.org/acrl/standards/informationliteracycompetency>.

${ }^{2}$ HOCHSCHULREKTORENKONFERENZ - Hochschulen im digitalen zeitalter: informationskompetenz neu begreifen: prozesse anders steuern. [Em linha]. Bonn: HRK, 2013. [Consult 15 jan. 2014]. Disponível na WWW em: <URL:http://www.hrk.de/fileadmin/redaktion/ hrk/02-Dokumente/02-10-Publikationsdatenbank/Beitr-2013-01_Informationskompetenz.pdf>. 
- "The fundamentals of recent developments in digital research processes should be taught, i.e. predominantly electronic publishing and open access, digital long-term archiving, dealing with virtual research environments and digital research data."

- "To improve the management of research data in particular it appears necessary for staff at university libraries and computer centers to expand their skills in the direction of profiles such as "Data Librarian" or "Data Curator". Higher education institutions should establish courses that will take account of this need for further specialisms."

The Master plan for Germany's information infrastructure by the Joint Science Conference recommends to support the university libraries to teach information literacy to students and scientific staff ${ }^{3}$. The Master plan states that

- "Knowledge of the importance of information literacy must be fixed in all parts of the society. Teaching information literacy must start in schools and continued systematically in unversities with modern didactical methods."

- "The university libraries must be supported in their task providing, basic services for teaching information literacy in all degree programms and for the scientific staff."

Finally, the commission "Internet and Digital Society" of the German Bundestag states significant shortfalls concerning the information competency of students and scientists and explicitly asks for the teaching of information literacy at schools and universities ${ }^{4}$. The commission explicitly says that "Teaching information literacy is a big challenge for

3 KOMMISSION ZUKUNFT DER INFORMATIONSINFRASTRUKTUR - Gesamtkonzept für die informationsinfrastruktur in Deutschland. [Em linha]. Bonn: 2011. [Consult 15 jan. 2014]. Disponível na WWW em: <URL:http://www.allianzinitiative.de/fileadmin/user_upload/ redakteur/KII_Gesamtkonzept.pdf $>$.

${ }^{4}$ DeUTSCHER BUNDESTAG - Internet-Enquete: Mai 2010 bis April 2013“. [Em linha]. Berlin: Deutscher Bundestag. [Consult 15 jan. 2014]. Disponível na WWW em: <URL:http:// webarchiv.bundestag.de/cgi/show.php?fileToLoad=2944\&id=1223>. 
teachers and students in nurseries, schools and universities due to the information overflow und the lack of the necessary competencies to find relevant and reliable information."

In the following chapters it will be analyzed how the German university libraries have accepted this challenge and developed courses and e-learning-programs.

\section{Information Literacy Statistics}

The German national library statistics ${ }^{5}$ count the information literacy lessons in university libraries since 2003 and the number of the participants since 2007. Lessons increased from 33.784 hours un 2003 to 50.339 hours in 2011, the number of participating students from 317.053 in 2007 to 527.781 in 2011 , However, human resources have not been increased: Contrary, the number of employees in the scientific libraries decreased from 11.871 in 2003 to 11.464 in 2011. Libraries could not employ additional staff members for the new task but had to reorganize the workload.

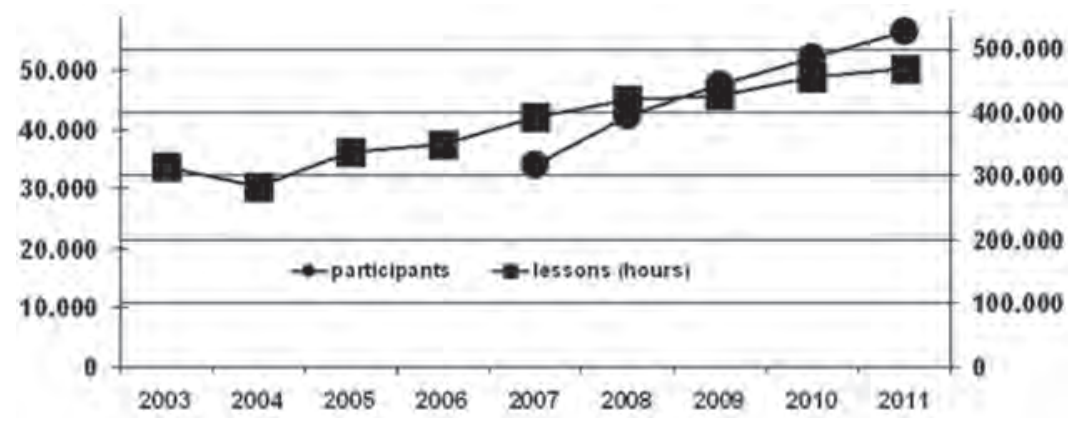

FIGURA 1: German library statistics: Information literacy lessons in university libraries (left axis) and participants(right axis)

5 DEUTSCHER BIBLIOTHEKSVERBAND - Standards der informationskompetenz für studierende. [Em linha]. Berlin: Deutscher Bibliotheksverband e.V., 2009. [Consult 15 jan. 2014]. Disponível na WWW em: <URL:http://www.bibliotheksverband.de/fileadmin/ user_upload/Kommissionen/Kom_Dienstleistung $>$. 
In order to describe in detail the information literacy courses, the library networks in the German states Bavaria, Baden-Württemberg und North Rhine-Westphalia developed in 2008 a specific information literacy statistics which contain 9 key figures ${ }^{6}$ :

- length of time of the information literacy courses

- number of participants

- field of study/subject of the participants

- course type

- course topics

- didactical methods

- target group

- deployed staff

- curricular integration

In the following, we discuss the results of the libraries in the Bavarian Consortia 2012. Most of the courses focus on library use (66,35\%) and particular catalogues and databases $(63,17 \%)$, but these advanced topics as search strategies in general, internet search and search engines, information and reference management, electronic publishing and legal and ethical issues. $80 \%$ are one-time-courses with a duration of 90 minutes.

More than half of the courses of the Bavarian university libraries $(63,58 \%)$ contains practical exercises or tutorials. Course rooms with training PCs, beamer and/or interactive whiteboards are available in all university libraries. The libraries agree that self-learn-parts are inevitable instructional components in order to fulfill the learning objectives. But just $20 \%$ of the courses are integrated into the curricula with credit points.

$60 \%$ of the participants are bachelor and master students. But also high school students constitute an important target group for the university libraries. More than $20 \%$ of the libraries are aimed at high school students or teachers. Normally, two main intentions are connected with

6 DEUTSCHE BIBLIOTHEKSVERBAND - Informationskompetenz-veranstaltungsstatistik. [Em linha]. Berlin: DBV. [Consult 15 jan. 2014]. Disponível na WWW em: <URL:http://www. informationskompetenz.de/veranstaltungsstatistik $>$. 
the activities for high schools: First, their students already get some skills they need for their university studies and which need not to be taught at the university later. And secondly, library courses can be considered as purposive marketing for the university.

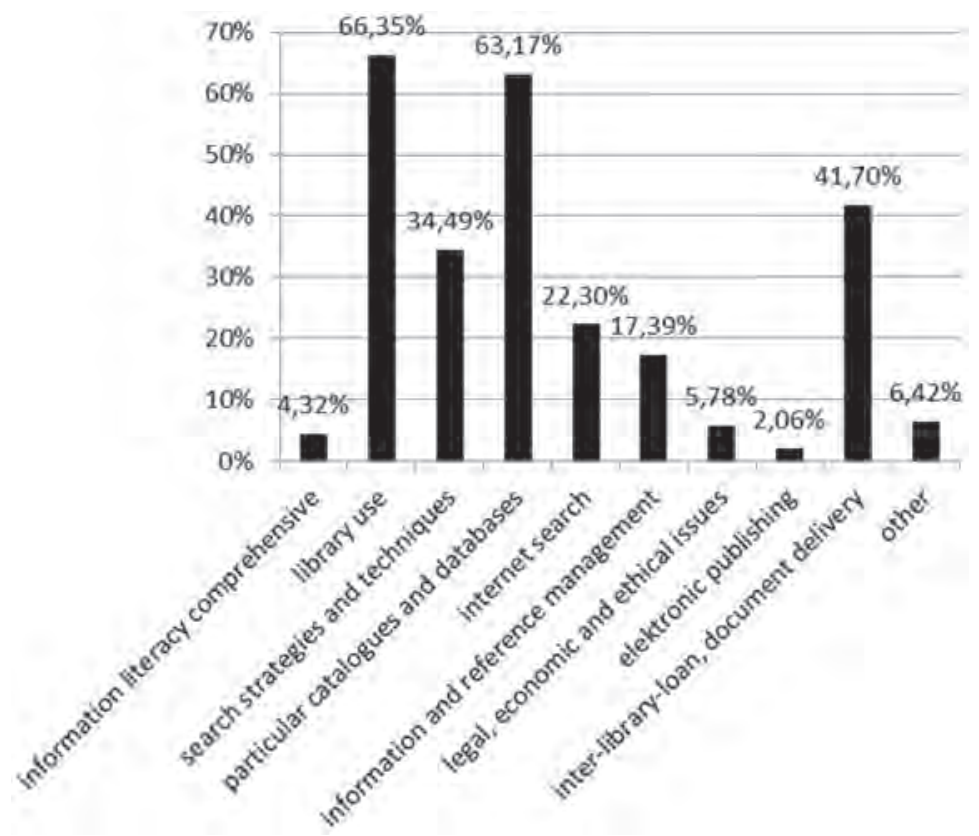

FIGURA 2: Topics of the information library courses in the Bavarian university libraries 2012

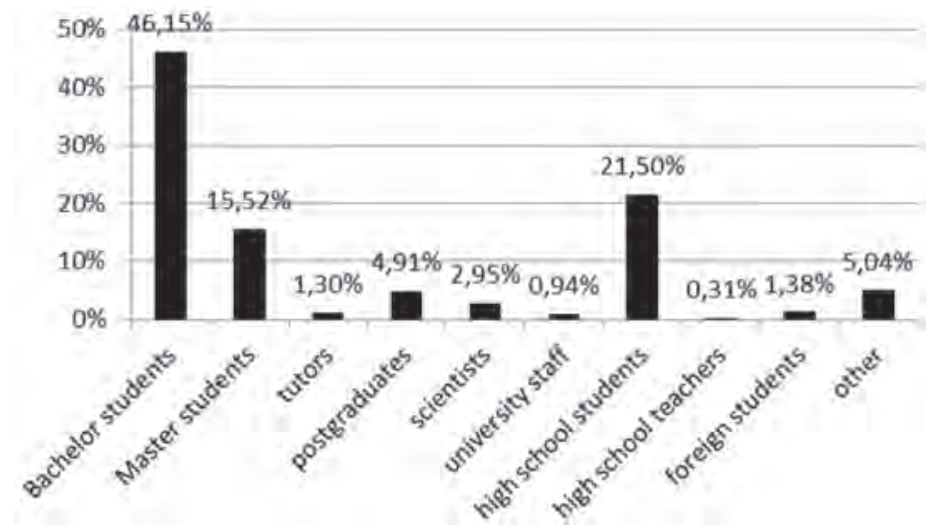

FIGURA 3: Target groups of the information library courses in the Bavarian university libraries 2012 


\section{Information Literacy Networks}

According to the federal structure of Germany, information literacy working groups have been launched first in the regional library networks since 2002. They support the field librarians, coordinate best practice, organize professional training and publish standards and recommendations. E.g., the Bavarian working group has arranged staff trainings with subjects

- Information Literacy Assessment

- Standards of Information Literacy for High School students

- Teaching Information Literacy to postgraduates.

Furthermore, the Bavarian network has initiated an inter-library peer consulting that turned out to be very successful and now goes into its fourth year. Teaching librarians from different libraries visit each other in groups of 4 or 5 persons. They attend information literacy courses and evaluate the concept and the performance of their colleagues. Workshops at the beginning, after the final round and in the middle ("pit stop") complete the program.

The main exchange and communication platform for the German teaching librarians is the website www.informationskompetenz.de. The heart of this platform is a database with more than 1.000 concepts, presentations, sample exercises and information literacy courses supplied by libraries that can be downloaded and used without restrictions. The information literacy statistics (see 2.) are located on this website, furthermore standards, position papers, declaration and statements are collected and presented.

The heart of this platform is a database with more than 1.000 concepts, presentations, sample exercises and information literacy courses supplied by libraries that can be downloaded and used without restrictions. The information literacy statistics is situated on this website, furthermore it collects and presents standards, position papers, declaration and statements. 


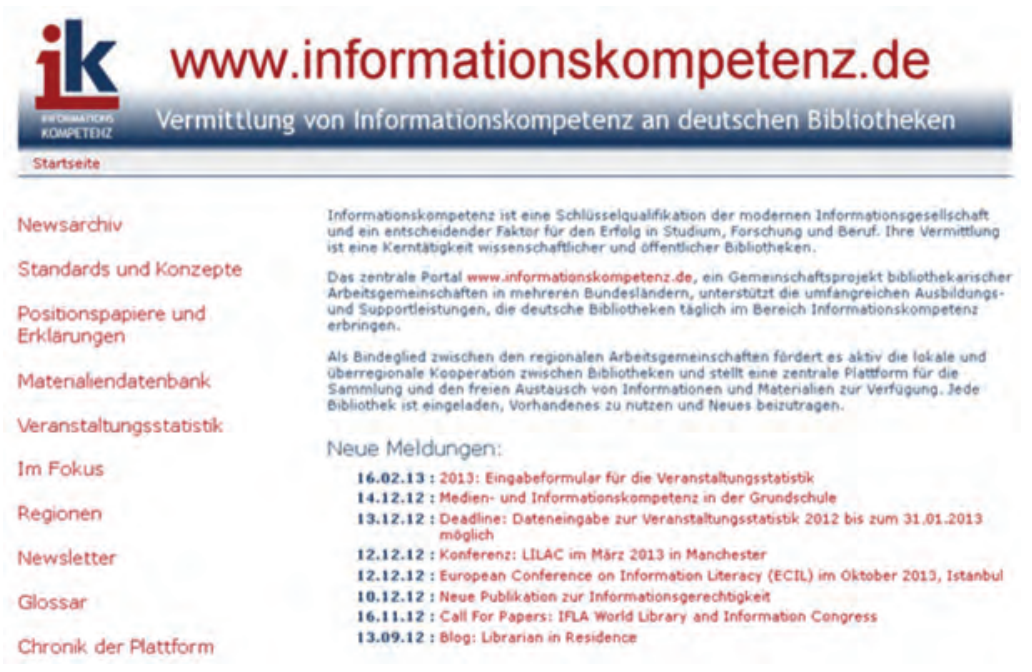

FIGURA 4: The national exchange und communication platform www.informationskompetenz.de

In 2012, the German Library Association and the Association of German Librarians founded the nationwide Commission for Information Literacy. Their tasks include

- monitoring the information literacy activities of the university and high schools

- acting as central contact for politics, science and libraries

- initiating projects for piloting and evaluating information literacy programs

- raising funding for the platform www.informationskompetenz.de

- organizing conferences to actual questions

- supporting the integration of information literacy into the curricula of universities and high schools

Actually, the commission is preparing a best-practice-competition and a round table in order to discuss, how new profiles like "data librarian" can be integrated into education and training of librarians. 


\section{Standards and Best Practice}

In 2009 the German Library Association adopted five information literacy standards for students ${ }^{7}$. They based on the Information Literacy Competency Standards for Higher Education of the US Association of College and Research Libraries (ACRL) ${ }^{8}$. Each standard is specified by indicators which describe the corresponding competencies. The German standards include:

1. Students recognize and express their need for information and determine nature and extent of the information needed.

2. Students access needed information effectively and efficiently.

3. Students evaluate information and its sources and select information according to their needs.

4. Students manage information effectively and present the results adopted to their audience with suitable technical means.

5. Students understand their responsibility while using and passing information.

6. The following examples show how the German university libraries handle these standards and transform them into their range of services:

- The courses of the university library Würzburg are integrated into the curricula of the Bachelor and Master degree programs and include ECTS points.

- The university library Bamberg offers courses about web-based information management and publishing.

- The university library Hannover offers workshops for scientific writing and electronic publishing.

7 DEUTSCHER BIBLIOTHEKSVERBAND - Standards der informationskompetenz für studierende. [Em linha]. Berlin: Deutscher Bibliotheksverband e.V., 2009. [Consult 15 jan. 2014]. Disponível na WWW em: <URL:http://www.bibliotheksverband.de/fileadmin/ user_upload/Kommissionen/Kom_Dienstleistung $>$.

8 ASSOCIATION OF COLLEGE \& RESEARCH LIBRARIES - Information literacy competency standards for higher education. [Consult 15 jan. 2014]. Disponível na WWW em: <URL:http:// www.ala.org/acrl/standards/informationliteracycompetency>. 
- A large number of university libraries offer trainings for reference management systems (Endnote, Citavi, Reference Manager).

- E-Tutorials of the university library Konstanz are integrated into the learning system of the university.

- The Bavarian library network developed cooperative e-tutorials for search strategies in databases.

- The Bavarian university libraries have signed an agreement with the Bavarian State Ministry of Education and Culture and the Bavarian State Ministry of Sciences, Research and the Arts defining the cooperation between libraries and high schools.

More information can be found in the references.

\section{Final Conclusion}

The actual achievements of the advancement of information literacy in German university libraries can be evaluated with the help of the nationwide information literacy statics which is one the most specific statistics in this field. There are promising approaches towards a comprehensive understanding of information literacy within the libraries and towards the integration of information literacy courses into the university curricula, which are backed by political and scientific committees in Germany. However, the libraries cannot count on funding for recruiting additional staff. Instead, they have to restructure the work design and to qualify the available staff.

\section{Referências bibliográficas}

ASSOCIATION OF COLLEGE \& RESEARCH LIBRARIES - Information literacy competency standards for higher education. [Em linha]. Chicago: ACRL, 2000. [Consult 15 jan. 2014]. Disponível na WWW em: <URL:http://www.ala.org/acrl/standards/ informationliteracycompetency>. 
DEUTSCHER BIBLIOTHEKSVERBAND - Informationskompetenz-veranstaltungsstatistik. [Em linha]. Berlin: DBV. [Consult 15 jan. 2014]. Disponível na WWW em: <URL:http://www.informationskompetenz.de/veranstaltungsstatistik>.

DEUTSCHER BIBLIOTHEKSVERBAND - Standards der informationskompetenz für studierende. [Em linha]. Berlin: Deutscher Bibliotheksverband e.V., 2009. [Consult 15 jan. 2014]. Disponível na WWW em: <URL:http://www.bibliotheksverband. de/fileadmin/user_upload/Kommissionen/Kom_Dienstleistung>.

DEUTSCHER BUNDESTAG - Internet-Enquete: Mai 2010 bis April 2013“. [Em linha]. Berlin: Deutscher Bundestag. [Consult 15 jan. 2014]. Disponível na WWW em: <URL:http://webarchiv.bundestag.de/cgi/show.php?fileToLoad=2944\&id=1223>. HOCHSCHULBIBLIOTHEKSZENTRUM DES LANDES NORDRHEIN-WESTFALEN - Deutsche bibliotheksstatistik. [Em linha]. Köln: hbz. [Consult 15 jan. 2014]. Disponível na WWW em: <URL: http://www.hbz-nrw.de/angebote/dbs>.

HOCHSCHULREKTORENKONFERENZ - Hochschulen im digitalen zeitalter: informationskompetenz neu begreifen: prozesse anders steuern. [Em linha]. Bonn: HRK, 2013. [Consult 15 jan. 2014]. Disponível na WWW em: <URL:http://www. hrk.de/fileadmin/redaktion/hrk/02-Dokumente/02-10-Publikationsdatenbank/ Beitr-2013-01_Informationskompetenz.pdf>.

KOMMISSION ZUKUNFT DER INFORMATIONSINFRASTRUKTUR - Gesamtkonzept für die informationsinfrastruktur in Deutschland. [Em linha]. Bonn: 2011. [Consult 15 jan. 2014]. Disponível na WWW em: <URL:http://Www.allianzinitiative.de/ fileadmin/user_upload/redakteur/KII_Gesamtkonzept.pdf>.

SÜHL-STROMENGER, Wilfried - Teaching library. Berlim: deGruyter, 2012.

SÜHL-STROMENGER, Wilfried (ed.) - Handbuch informationskompetenz. Berlim: deGruyter, 2012. 
José Augusto Cardoso Bernardes é Professor da Faculdade de Letras da Universidade de Coimbra e Diretor da Biblioteca Geral da Universidade

Ana Maria Eva Miguéis é coordenadora do Serviço Integrado das Bibliotecas da Universidade de Coimbra

Carla Ferreira é bibliotecária nos Serviços de Biblioteca e Documentação da Faculdade de Letras da Universidade de Coimbra. 


\section{Série Documentos}

Imprensa da Universidade de Coimbra

Coimbra University Press

2015

C •

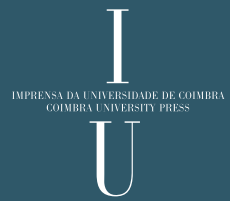

